CLINICAL STUDY

\title{
Pegvisomant interference in GH assays results in underestimation of GH levels
}

\author{
A N Paisley, K Hayden ${ }^{2}$, A Ellis ${ }^{3}$, J Anderson ${ }^{1}$, G Wieringa ${ }^{1}$ and P J Trainer \\ Department of Endocrinology, Christie NHS Trust, Wilmslow Road, Withington, Manchester M2O 4BX, UK, ${ }^{1}$ Department of Biochemistry, Christie \\ Hospital, Manchester, UK, ${ }^{2}$ Department of Clinical Biochemistry, University Hospital Aintree, Liverpool, UK and ${ }^{3}$ UK NEQAS, Department of Clinical \\ Biochemistry, Royal Infirmary, Edinburgh, UK \\ (Correspondence should be addressed to P J Trainer; Email: peter.trainer@man.ac.uk)
}

\begin{abstract}
Introduction: Pegvisomant use in acromegaly negates the use of GH levels to monitor disease activity. To achieve antagonism, plasma concentrations must be $\sim 1000$-fold greater than GH which with the high homology between the peptides makes $\mathrm{GH}$ measurement a challenge when pegvisomant is present.

Objective: We investigated the effect of pegvisomant on GH measured using commercially available assays.

Methods: Pooled serum samples with GH concentrations $<0.38$, 3.85 and $7.69 \mu \mathrm{g} / \mathrm{l}$ were spiked with increasing pegvisomant concentrations (9000-494 000 $\mathrm{g} / \mathrm{l})$. Samples were analysed by the Nichols Advantage, DPC Immulite 2000, Diasorin IRMA, Beckman Access Dxl, Tosoh AIA and Wallac Delfia assays.

Results: With baseline $\mathrm{GH}<0.38 \mu \mathrm{g} / \mathrm{l}$ measured levels were $<0.38$ in all assays except Nichols, Diasorin and Beckman where GH peaked at 1.5, 9.6 and $17.7 \mu \mathrm{g} / \mathrm{l}$ respectively at low pegvisomant concentrations, falling thereafter. With the other two samples, measured GH levels progressively fell with increasing pegvisomant concentrations, except the Beckman assay where an increase $(30.8 \mu \mathrm{g} / \mathrm{l})$ was seen at a pegvisomant concentration of $9000 \mu \mathrm{g} / \mathrm{l}$; and Diasorin and Tosoh where smaller increases were seen at lower pegvisomant concentrations, levels gradually falling thereafter. Conclusion: The presence of pegvisomant resulted in artefactually low measured GH in most assays. We speculate this fall is due to assay antibody-binding pegvisomant, reducing the amount of available antibody to bind actual GH thereby producing less sandwich formation: the 'high-dose hook' effect. In most assays, this effect is modest and results in lower $\mathrm{GH}$, but the level of interference makes them unsuitable for studies on the influence of pegvisomant on GH neuroregulation.
\end{abstract}

European Journal of Endocrinology 156 315-319

\section{Introduction}

Acromegaly is due to hypersecretion of growth hormone $(\mathrm{GH})$ usually from a benign pituitary somatotroph adenoma. Circulating GH stimulates the production of insulin-like growth factor-I (IGF-I), the effector molecule responsible for many of the signs and symptoms. GH is a 191-residue peptide which binds to a preformed dimer of identical transmembrane cell surface receptors to induce signal activation and IGF-I generation (1). Pegvisomant is a new GH competitive receptor antagonist that has recently been licensed for use in acromegaly. It is a genetically engineered $\mathrm{GH}$ analogue that differs from wild-type (wt) GH by eight mutations in the region of binding site 1 (2). A single amino acid substitution in the region of binding site 2 (an alanine to glycine substitution at position 120) allows binding to the receptor dimer but prevents the induction of the conformational change necessary for
GH signal transduction and IGF-I synthesis and secretion (3). Pegylation (conjugation of PEG $5000 \mathrm{kDa}$ moieties to lysines in the peptide) of the analogue reduces its clearance rate, increases circulating half-life and possibly reduces antigenicity. However, pegylation also reduces the affinity of pegvisomant for the GH receptor which means that to achieve adequate $\mathrm{GH}$ antagonism up to 1000-fold greater concentrations of pegvisomant are needed compared with GH. Pegvisomant has a 30-fold greater affinity for the GH-binding protein compared with the GH receptor $(1,4)$.

Consensus criteria suggest remission of acromegaly is achieved when there is normalisation of age- and sexmatched serum IGF-I levels with suppression of serum GH to $<1 \mu \mathrm{g} / \mathrm{l}$ after the administration of $75 \mathrm{~g}$ oral glucose $(5,6)$. By virtue of its mechanism of action IGF-I is the sole marker of disease activity in patients receiving pegvisomant, as unlike other medical therapies it makes no attempt to reduce circulating GH levels. 
Normalisation of IGF-I has been reported in 97\% patients on this therapy with concomitant improvement in associated intermediary metabolic abnormalities such as glucose intolerance (7).

Pegvisomant is commenced at a starting dose of $10 \mathrm{mg} /$ day increasing up to $40 \mathrm{mg} /$ day as necessary to control serum IGF-I levels. Equivalent serum pegvisomant concentrations have been measured at up to $50000 \mu \mathrm{g} / \mathrm{l}$ with these doses (8). Serum levels increase further (up to $80000 \mu \mathrm{g} / \mathrm{l}$ ) with the addition of octreotide therapy (8). Other studies have confirmed the high pegvisomant concentrations required to achieve GH antagonism with mean doses of around $16 \mathrm{mg} /$ day producing mean plasma pegvisomant concentrations of around $13330 \mu \mathrm{g} / \mathrm{l}(9)$.

Although GH cannot be used as a measure of disease activity, it may still be measured in research for studies of GH neuroregulation. There is also the worry that it may be unintentionally measured and clinical decisions made upon its results. Owing to its high structural homology to $\mathrm{GH}$, the presence of pegvisomant in serum is likely to result in interference resulting in inaccurate GH estimations when measured using conventional assays. Special GH assays have been developed eliminating any interference and cross-reactivity, however, this is only available for research purposes $(10,11)$.

We aimed to investigate the effect of pegvisomant on GH measurement using six commonly available commercial assays.

\section{Methods}

A total of $20 \mathrm{mg}$ pegvisomant powder was dissolved in $2 \mathrm{ml}$ de-ionised water by mixing at room temperature for $10 \mathrm{~min}$ to give a stock solution of $10 \mathrm{mg} / \mathrm{ml}$ $(10000 \mu \mathrm{g} / \mathrm{ml})$. Three pooled serum samples of different GH concentrations $(\mathrm{GH}<0.38$, approximately 3.9 and $7.7 \mu \mathrm{g} / \mathrm{l}$ as measured on the Nichols Advantage (Nichols Institute Diagnostics, San Clemente, CA 92673, USA)) were prepared and 'spiked' with the stock solution to give increasing pegvisomant concentrations of $9000,20000,41000,82000$ and $494000 \mu \mathrm{g} / \mathrm{l}$. Samples were collected from patients who had never received treatment with pegvisomant. Aliquots of the preparations were stored at $-20{ }^{\circ} \mathrm{C}$ prior to dispatch to the participating laboratories. Analyses were performed in singlicate.

GH was analysed in each sample using widely available commercial assays: the Nichols Advantage, DPC Immulite 2000 (Diagnostics Products Corporation, Gwynned, UK), Diasorin IRMA (DiaSorin Ltd, Wokingham, UK), Beckman Access Dxl (Beckman Coulter UK Ltd, High Wycombe, UK), Tosoh AIA (TOSOH Bioscience, Inc., San Francisco, CA 94080, USA) and Wallac Delfia (Perkin-Elmer Life and Analytical Sciences, Turku, Finland; Table 1).

All assays are solid phase, two-site immunometric sandwich assays (Table 1). Serum samples containing $\mathrm{GH}$ are incubated with an immobilised antibody (monoclonal) directed against a specific site on the GH molecule and a labelled second antibody (monoclonal/ polyclonal) used as a tracer directed against a separate antigenic site. During incubation, the tracer binds to the solid phase following which the amount of bound labelled antibody is proportional to the concentration of $\mathrm{GH}$ in the sample. All assays are calibrated to WHO NIBSC standards.

\section{Results}

\section{Sample 1 (Baseline GH $<0.4 \mu g / l)$}

Levels remained $<0.4 \mu \mathrm{g} / \mathrm{l}$ in three of the assays (Wallac, Tosoh and DPC Immulite) at all concentrations of pegvisomant. For the Beckman Access Dxl assay, measured GH levels peaked at $17.7 \mu \mathrm{g} / \mathrm{l}$ at a pegvisomant concentration of $20000 \mu \mathrm{g} / \mathrm{l}$; for the Diasorin assay GH peaked at $9.8 \mu \mathrm{g} / \mathrm{l}$ at a pegvisomant concentration of $9000 \mu \mathrm{g} / \mathrm{l}$ and in the Nichols assay $\mathrm{GH}$ peaked at $1.5 \mu \mathrm{g} / \mathrm{l}$ at a pegvisomant concentration

Table 1 Growth hormone assays used.

\begin{tabular}{|c|c|c|c|c|c|c|}
\hline Assay & Assay design & $\begin{array}{l}\text { Incubation } \\
\text { time (min) }\end{array}$ & Antibodies used & $\begin{array}{c}\text { Analytical } \\
\text { sensitivity } \\
\text { (manufacturer } \\
\text { provided; } \mathrm{ng} / \mathrm{ml} \text { ) }\end{array}$ & $\begin{array}{c}\text { Intraassay } \\
\text { variation } \\
(\% \mathrm{CV})\end{array}$ & $\begin{array}{l}\text { WHO } \\
\text { calibration }\end{array}$ \\
\hline Nichols Advantage & Simultaneous & 60 & $\begin{array}{l}\text { One mouse monoclonal } \\
\text { and one goat polyclonal }\end{array}$ & 0.1 & $\begin{array}{l}<6 \% \text { at GH } \\
>2 \mathrm{ng} / \mathrm{ml}\end{array}$ & 1st IS $80 / 505$ \\
\hline DPC Immulite 2000 & Sequential & 30 & $\begin{array}{l}\text { One murine monoclonal } \\
\text { and one rabbit polyclonal }\end{array}$ & 0.01 & $\begin{array}{l}<7 \% \text { at } \mathrm{GH} \\
>2.5 \mathrm{ng} / \mathrm{ml}\end{array}$ & 2nd IS 98/574 \\
\hline Diasorin IRMA & Simultaneous & 90 & Two mouse monoclonal & 0.2 & $\begin{array}{l}<6 \% \text { at GH } \\
>1 \mathrm{ng} / \mathrm{ml}\end{array}$ & 1st IS $80 / 505$ \\
\hline $\begin{array}{l}\text { Beckman Access } \\
\text { Dxl }\end{array}$ & Simultaneous & 42 & $\begin{array}{l}\text { One mouse monoclonal } \\
\text { and one goat polyclonal }\end{array}$ & 0.003 & $\begin{array}{l}<8 \% \text { at GH } \\
>0.1 \mathrm{ng} / \mathrm{ml}\end{array}$ & 1st IS $80 / 505$ \\
\hline Tosoh AIA & Sequential & 30 & Two mouse monoclonal & 0.07 & $\begin{array}{l}<6 \% \text { at GH } \\
>2 \mathrm{ng} / \mathrm{ml}\end{array}$ & 2nd IS $98 / 574$ \\
\hline Wallac Delfia & Simultaneous & 120 & Two mouse monoclonal & 0.01 & $\begin{array}{l}<2.5 \% \text { at } \mathrm{GH} \\
>0.4 \mathrm{ng} / \mathrm{ml}\end{array}$ & 1st IS $80 / 505$ \\
\hline
\end{tabular}


of $20000 \mu \mathrm{g} / \mathrm{l}$. In all of these assays, measured $\mathrm{GH}$ levels then fell progressively with further increases in pegvisomant concentrations (Fig. 1).

\section{Sample 2 (Baseline GH $\sim 3.9 \mu \mathrm{g} / \mathrm{l})$}

For most assays, measured GH fell as the pegvisomant concentration rose. Exceptions were the Beckman Access Dxl assay where a ninefold increase in measured $\mathrm{GH}$ was seen at $30 \mu \mathrm{g} / \mathrm{l}$ and the Diasorin assay where measured levels increased to $10 \mu \mathrm{g} / \mathrm{l}$, in both cases at pegvisomant concentrations of $9000 \mu \mathrm{g} / \mathrm{l}$. Modest increases were also seen in the Tosoh assay. As before $\mathrm{GH}$ levels then fell progressively as the pegvisomant concentration increased (Fig. 2).

\section{Sample 3 (Baseline GH $\sim 7.7 \mu g / l$ )}

Results were similar to those reported when baseline $\mathrm{GH}$ was $\sim 3.9 \mu \mathrm{g} / \mathrm{l}$ where a progressive fall in measured $\mathrm{GH}$ was seen with increasing pegvisomant concentrations. However a fourfold rise in measured $\mathrm{GH}$ was seen for the Beckman Access Dxl assay to $31.5 \mu \mathrm{g} / \mathrm{l}$ at a pegvisomant concentration of $9000 \mu \mathrm{g} / \mathrm{l}$ and the Diasorin assay peaked at $8.9 \mu \mathrm{g} / \mathrm{l}$ at the same pegvisomant concentration with reduction in $\mathrm{GH}$ levels thereafter (Fig. 3).

\section{Discussion}

We have investigated the effect of differing pegvisomant concentrations on GH measurement using widely available commercial assays (Nichols Advantage, DPC Immulite 2000, Diasorin IRMA, Beckman Access Dxl, Tosoh AIA and Wallac Delfia). Baseline differences are seen in GH levels which reflect the known assay bias. Results demonstrate that in most $\mathrm{GH}$ assays the

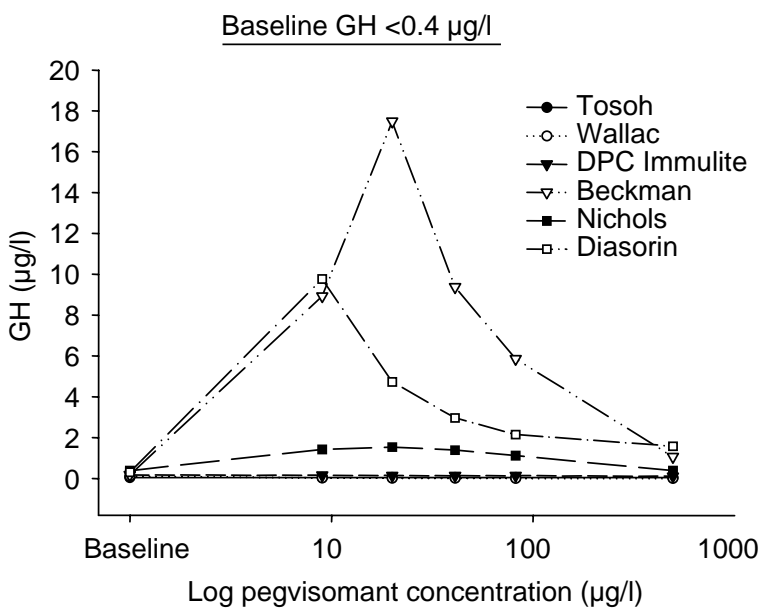

Figure 1 Results of spiking increasing concentrations of pegvisomant into a sample containing $<0.4 \mu \mathrm{g} / \mathrm{l} \mathrm{GH}$.

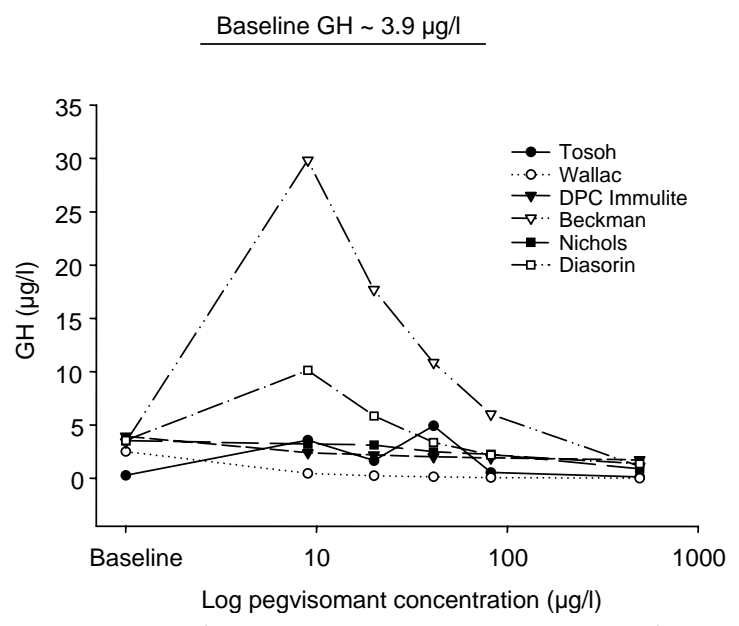

Figure 2 Results of spiking increasing concentrations of pegvisomant into a sample containing $\sim 3.9 \mu \mathrm{g} / \mathrm{l} \mathrm{GH}$.

presence of pegvisomant leads to a reduction in measured plasma GH levels with a progressive decline seen at higher pegvisomant concentrations. In three assays (the Nichols Advantage, Beckman Access Dxl and Diasorin IRMA), the progressive fall in GH levels was preceded by an initial increase. These data confirm our knowledge that GH cannot be reliably measured in patients on pegvisomant in commercially available assays, but contradicts previous predictions that crossreactivity would result in artefactually high levels of GH.

We postulate that one of three mechanisms may be important in the effect of pegvisomant on observed GH concentrations:

1 As stated before, each molecule of pegvisomant is pegylated (PEG). PEG has historically been used in immunoassays as part of second antibody separation procedures where it works not by binding antibody but enhancing antibody-antigen interactions (by

Baseline $\mathrm{GH} \sim 7.7 \mu \mathrm{g} / \mathrm{l}$

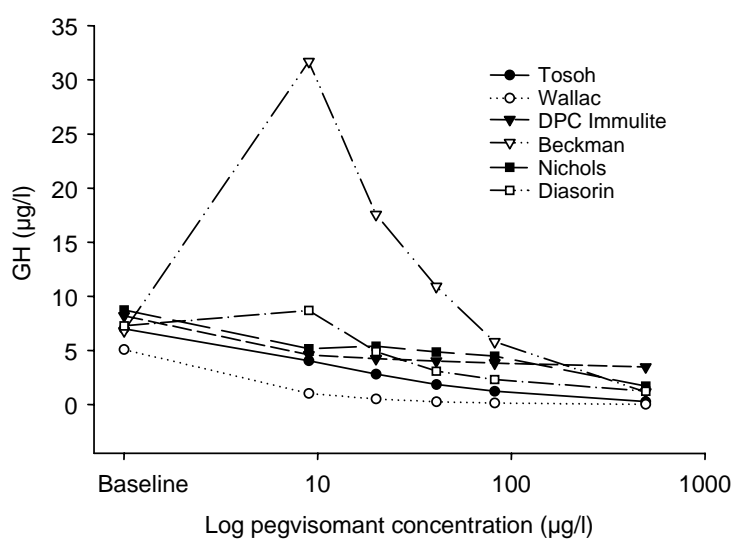

Figure 3 Results of spiking increasing concentrations of pegvisomant into a sample containing $\sim 7.7 \mu \mathrm{g} / \mathrm{l} \mathrm{GH}$. 
removing water/hydrophilic residues). Although its presence would not actually bind the antigen or antibody causing any interference, it is possible that the sheer concentration of PEG present produces steric hindrance in the sandwich complex binding. This is particularly likely at the highest concentrations of pegvisomant $(494000 \mu \mathrm{g} / \mathrm{l})$ where there are four to six molecules of PEG present per molecule of pegvisomant. This study demonstrates that the effect of PEG in any given assay system is unpredictable.

2 Pegvisomant could be acting as an antigen binding to one, but not both, of the antibodies. This would prevent sandwich formation and therefore decrease measured GH levels as seen in some assays with increasing pegvisomant concentrations. Supporting this theory are the findings by Thorner et al. (10), who employed two strategies for measuring $\mathrm{GH}$ levels in healthy young men following the administration of pegvisomant in doses up to $1 \mathrm{mg} / \mathrm{kg}$. GH was measured using a modified Nichols chemiluminescence assay (empirically corrected for pegvisomant cross-reactivity), and a direct $\mathrm{GH}$ two-site immunoassay using two monoclonal antibodies with high affinity for GH but no crossreactivity with PEG up to a concentration of $50000 \mu \mathrm{g} / \mathrm{l}$. Concordance in GH levels was found between the assays with no significant change in GH levels at any dose.

3 Owing to the high structural homology to GH, pegvisomant could act as an antigen binding to both antibodies and permitting sandwich formation. Therefore, measured GH could increase in the presence of pegvisomant. However, the 'high-dose hook' effect (excess concentration of pegvisomant results in saturation of available antibody sites resulting in failure of $\mathrm{GH}$ sandwich complex formation) may act to decrease observed $\mathrm{GH}$ as pegvisomant concentration increases. This could explain the pattern seen in the Beckman Access Dxl and Diasorin IRMA assays. The range of pegvisomant concentrations used in this study was chosen to reflect levels achieved in clinical practise. Further studies would be necessary to explore the 'hook effect' using lower concentrations of pegvisomant.

We cannot say with confidence which of these mechanisms is applicable to any one assay - more than one may be in play in each assay. However, it should be noted that the 'high-dose hook' effect could explain all the observations, assuming that the hook point in those assays that did not show an initial increase in observed GH actually occurred at some pegvisomant concentration lower than the lowest spike.

Given the nature of interference of pegvisomant in commercial assays producing artefactually lower and higher levels of GH than the predicted excessively high levels, incorrect interpretations of results could occur.
It may be that GH levels appear of a plausible range, in keeping with what would be expected and hence are not recognised as incorrect. Therefore, if $\mathrm{GH}$ is to be measured it is critical that specific assays which detect only true GH levels with no cross-reactivity from the presence of pegvisomant are developed for commercial use.

In summary, we have demonstrated pegvisomant to interfere negatively with GH with lower levels measured with higher concentrations of pegvisomant. In most assays, the effect of pegvisomant at therapeutic concentrations is modest and results in lower GH, but the level of interference makes them unsuitable for studies on the influence of pegvisomant on GH neuroregulation.

\section{References}

1 Ross RJ, Leung KC, Maamra M, Bennett W, Doyle N, Waters MJ \& Ho KK. Binding and functional studies with the growth hormone receptor antagonist, B2036-PEG (pegvisomant), reveal effects of pegylation and evidence that it binds to a receptor dimer. Journal of Clinical Endocrinology and Metabolism 200186 1716-1723.

2 Kopchick JJ, Parkinson C, Stevens EC \& Trainer PJ. Growth hormone receptor antagonists: discovery, development, and use in patients with acromegaly. Endocrine Reviews 200223 623-646.

3 Pradhananga S, Wilkinson I \& Ross RJ. Pegvisomant: structure and function. Journal of Molecular Endocrinology 200229 11-14.

4 Trainer PJ, Drake WM, Katznelson L, Freda PU, Herman-Bonert V, Van Der Lely AJ, Dimaraki EV, Stewart PM, Friend KE, Vance ML, Besser GM, Scarlett JA, Thorner MO, Parkinson C, Klibanski A, Powell JS, Barkan AL, Sheppard MC, Malsonado M, Rose DR, Clemmons DR, Johannsson G, Bengtsson BA, Stavrou S, Kleinberg DL, Cook DM, Phillips LS, Bidlingmaier M, Strasburger CJ, Hackett S, Zib K, Bennett WF \& Davis RJ. Treatment of acromegaly with the growth hormone-receptor antagonist pegvisomant. New England Journal of Medicine 2000 342 1171-1177.

5 Giustina A, Barkan A, Casanueva FF, Cavagnini F, Frohman L, Ho K, Veldhuis J, Wass J, Von Werder K \& Melmed S. Criteria for cure of acromegaly: a consensus statement. Journal of Clinical Endocrinology and Metabolism 200085 526-529.

6 Trainer PJ. Editorial: acromegaly-consensus, what consensus? Journal of Clinical Endocrinology and Metabolism 200287 3534-3536.

7 Van Der Lely AJ, Hutson RK, Trainer PJ, Besser GM, Barkan AL, Katznelson L, Klibanski A, Herman-Bonert V, Melmed S, Vance ML, Freda PU, Stewart PM, Friend KE, Clemmons DR, Johannsson G, Stavrou S, Cook DM, Phillips LS, Strasburger CJ, Hackett S, Zib KA, Davis RJ, Scarlett JA \& Thorner MO. Long-term treatment of acromegaly with pegvisomant, a growth hormone receptor antagonist. Lancet $20013 \mathbf{3 8} 1754-1759$.

8 Van Der Lely AJ, Muller A, Janssen JA, Davis RJ, Zib KA, Scarlett JA \& Lamberts SW. Control of tumor size and disease activity during cotreatment with octreotide and the growth hormone receptor antagonist pegvisomant in an acromegalic patient. Journal of Clinical Endocrinology and Metabolism 200186 478-481.

9 Parkinson C, Burman P, Messig M \& Trainer PJ. Gender, body weight, disease activity, and prior radiotherapy influence the response to pegvisomant. Journal of Clinical Endocrinology and Metabolism 200792 190-195.

10 Thorner MO, Strasburger CJ, Wu Z, Straume M, Bidlingmaier M, Pezzoli SS, Zib K, Scarlett JC \& Bennett WF. Growth hormone (GH) receptor blockade with a PEG-modified GH (B2036-PEG) lowers 
serum insulin-like growth factor-I but does not acutely stimulate serum GH. Journal of Clinical Endocrinology and Metabolism 1999 $842098-2103$.

11 Veldhuis JD, Bidlingmaier M, Anderson SM, Wu Z \& Strasburger CJ. Lowering total plasma insulin-like growth factor I concentrations by way of a novel, potent, and selective growth hormone $(\mathrm{GH})$ receptor antagonist, pegvisomant (B2036-peg), augments the amplitude of GH secretory bursts and elevates basal/nonpulsatile $\mathrm{GH}$ release in healthy women and men. Journal of Clinical Endocrinology and Metabolism $2001 \mathbf{8 6}$ $3304-3310$

Received 29 August 2006

Accepted 5 December 2006 